EWA GOCZAŁ

Uniwersytet Pedagogiczny im. KEN w Krakowie

e.goczal@gmail.com

\title{
MIĘDZY LIRYKĄ BEATU A WIERSZEM PROJEKCYJNYM: PIOTR SOMMER I SZTUKA TRANSFERU POEZJI (UJĘCIE W PLANIE AMERYKAŃSKIM)
}

\section{Abstract \\ Between Beat Poetry and Projective Poem: Piotr Sommer and the Art of Poetry Transfer ("American Shot" Perspective)}

The article analyses Piotr Sommer's achievements in translation. The art of transfer is considered here as both the act of translation and revelation - joining translation of literary texts and their compilation in anthologies with scrutinizing particular writers and literary phenomena as well as the process of translation itself, and introducing a new transforming quality to native poetry. A translator-anthologist can be perceived from that perspective as a link between two literary cultures, and also as an initiator of changes and an independent creator who develops, in his own language and on his own conditions, a new canon of poetry. Even if it is a paradoxical avant-garde canon, it is all the more inspiring for innovative actions.

The notion of American shot, used as a metaphor and figure of interpretation, is consolidated by limiting the materials to translations from New York poetsi - these are the most specific for the work and included in two significant books: Artykuty pochodzenia zagranicznego (1996) and the extended version $O$ krok od nich from (2006). This perspective enables one to present poetry transfer as the art of registration (in a new language) and projection (in a new context) of textual reflections of literary imagination. The American poets are presented here against the background of Marshall Berman's philosophical concept of modernism and within the framework of Marjorie Perloff's critical and literary thought. The figure of John Ashbery, as the creator of the most eccentric and self-contained and, simultaneously, influential poetry, is moving towards centre stage here. Apart from the general recognitions concerning Sommer's translation 
and compilation methods, the article includes in-depth analysis of one Ashbery's poem, especially emblematic for the discussed issues.

Key words: Piotr Sommer, beat poetry, projective poem, poetry transfer

Słowa klucze: Piotr Sommer, poezja bitników, wiersz projekcyjny, transfer poetycki

The window giving on shade, Is that here too? John Ashbery

\section{Zarys}

Polisemantyczny charakter słowa „transfer” pozwala posługiwać się nim jako terminem precyzyjnym i pojemnym, ale też elastycznym. Słowo to, mocno funkcjonujące w dyskursie przekładoznawczym, wspomagane jest przeważnie dookreśleniami, dzięki czemu zyskuje w poszczególnych użyciach walor formuły wyspecyfikowanej, dobranej z rozmysłem do konkretnego przedmiotu opisu. Na szerokim pograniczu pomiędzy translatologią a literaturoznawstwem pojęcie transferu - a w przyjętej tutaj perspektywie służyć ono będzie do opisu takiej działalności przekładowej, w której równorzędne wobec tłumaczeń wybranych tekstów jest przyswajanie i propagowanie stojących za nimi strategii artystycznych - może objaśnić odnośne zjawisko kompleksowo, odróżniając je od innych i sygnalizując jednocześnie jego wieloaspektowość. Brzmi może nieco tautologicznie (wiadomo, że translatio pochodzi od transfero), ale dobrze skontekstualizowany ,transfer” mówi nieco więcej i trochę co innego niż ,translacja”. Akcent pada tu na ustawiczność i równoczesność przesyłu danych, angażującą dwie strony dialogiczność, a także walor pozyskiwania wybitnych jednostek oraz przekształcania $\mathrm{i}$ - w zamierzeniu - doskonalenia działalności literackiej na polu własnego języka ${ }^{1}$. Translacja rozumiana jest tutaj - dla uściślenia

1 W dużym skrócie - i w stosownej tutaj perspektywie porównawczej - historię „Transfer-oriented Translation Studies" referuje Tamara Brzostowska-Tereszkiewicz w studium Komparatystyka literacka wobec translatologii. Przeglad stanowisk badawczych (zob. Brzostowska-Tereszkiewicz 2004: 313-318; por. Bukowski, Heydel 2009: 5-6, 33-34). W badaniach zorientowanych literaturoznawczo definicję transferu można wyprowadzić $\mathrm{z}$ prymarnego użycia tego pojęcia $\mathrm{w}$ innych dziedzinach. Taka definicja może połączyć jego ,przestrzenny” wymiar - proste przeniesienie czegoś z miejsca na miejsce, element 
terminologii - jako praktyczna część procesu tłumaczenia, by odnieść się do semantyki biologicznej, w której tym mianem określa się swoiste ,,przełożenie" informacji genetycznej na strukturę białka - proces dobrze poznany, powtarzalny, zachodzący zgodnie z podstawowymi prawidłami natury, organiczny, ale dający się przedstawić w postaci mechanicznego schematu. Jest ona nieodzowną częścią transferu, ale poza nią w jego obrębie znajdują się inne znaczące elementy.

Formułą „,sztuka transferu” można lapidarnie streścić działalność translatorską Piotra Sommera, opartą na intensywnie odczuwanej i podkreślanej w licznych wypowiedziach odpowiedzialności za właściwie wszystkie aspekty procesu spolszczania obcojęzycznej poezji. Mowa o tłumaczu, który przekłada teksty poetyckie, układa je w antologie i wzmacnia objaśnieniami w taki sposób, że objawia polskiej publiczności wyraziste osobowości twórcze, a przy tym wydobywa z innych literatur wartości, których w rodzimej literaturze - jego zdaniem - wcześniej brakowało. Anektuje je równocześnie do własnej poezji i proponuje innym jako potencjalny poetycki zysk. Takie jest wyraźnie wynikające z krytycznej obudowy założenie, ale takie są również widoczne z perspektywy czasu efekty. Można by mówić o tym w czasie przeszłym - istotne dla polskiej kultury literackiej przekłady z O’Hary, Reznikoffa, Ginsberga i Ashbery'ego, zainicjowane i w dużej mierze dokonane przez autora Artykułów pochodzenia zagranicznego, najsilniej promieniowały w latach 90 . Trudno jednak za spełnione uznać dzieło w ruchu - ciągle żywy konglomerat wierszy, rozmów i esejów. Daje się on odtwarzać we wciąż zmieniających się okolicznościach jak układ obrazów zarejestrowanych na taśmie filmowej, co jest tutaj istotne ze względu na porządkujące całość wywodu odniesienie do kompozycji fotograficznej. Tak bowiem można zobaczyć dziś całokształt Sommerowskich działań transferowych - dla większej klarowności zawężony tutaj do przekładów z poetów amerykańskich i ujęty w metaforę tego planu filmowego, który najlepiej przystaje do dialogicznej sytuacji przekładu.

„transakcyjny” - ugodę między dwiema stronami, z których jedna przesyła drugiej coś lub kogoś wartościowego, z czynnikiem ,edukacyjnym” - znanym psychologii przenoszeniem nawyków zdobytych przy opanowywaniu jednej umiejętności na uczenie się czegoś nowego (zob. SJP PWN). Transfer literacki pozwala zatem na włączenie do jednej rzeczywistości literackiej elementów innej (w bliskim myśli awangardowej rozumieniu utworu jako autonomicznej „,rzeczy”, a nie odbicia rzeczywistości), pozyskanie przez jeden krąg kulturowy osobowości twórczych z innego, a także poszerzenie świadomości i umiejętności tłumaczy oraz pisarzy kultury docelowej. 


\section{Perspektywa}

W sztuce montażu filmowego plan amerykański służy do rejestrowania rozmów, ukazywania relacji między jednostkami, na których koncentruje się uwaga widza. Ma to być relacja dynamiczna, więc ujęcie musi sugerować ruch, napięcie, przepływ emocjonalnej i intelektualnej energii. Patrzymy na postaci w centrum - z tak bliska, że widoczne są ich gesty oraz mimika - ale nie tracimy z oczu otoczenia, które powinno być adekwatne, dopowiadać coś do rozmowy i przydawać jej wiarygodności. Tło, jeśli jest dobrze zestrojone $\mathrm{z}$ innymi elementami, nadaje ton i głębię. $\mathrm{Z}$ pierwszym spojrzeniem mniej więcej rozpoznane, potem nie przyciąga już wzroku, choć nie przestaje znaczyć. Wszystko to razem dla koherencji i czytelności potrzebuje ramy. Pole wygenerowanego obrazu musi być ograniczone, przycięte według pewnych założeń - tylko takie będzie zapisem rzeczywistości i jednocześnie nową, dającą się zgłębić artystyczną całością (por. np. Płażewski 1961: 49-50).

Taki plan zdjęciowy może posłużyć jako metafora sytuacji przekładowej, w której za postaci centralne uznamy autora oryginału oraz thumacza, wypowiadających się poprzez teksty, a otoczonych i ograniczonych przez złożony układ kontekstów, które należy ustalić i objaśnić. Tłem musi zatem być nowoczesność, widziana tutaj przez pryzmat filozoficznych koncepcji Marshalla Bermana jako suma pojedynczych egzystencji nastawionych na upodmiotowienie. Ramą będzie pewna systematyzująca koncepcja, porządkująca istotne tu poetyki według klucza nieokreśloności języka zaczerpniętego z krytyki Marjorie Perloff. Plan wypełni szereg poetów amerykańskich, spośród których głos (rozpoznawalny, dobrze przez tłumacza ustawiony w polszczyźnie) zabierze kilku. Ich dobór i sposób ujęcia scharakteryzuje technikę translacyjną i kompilacyjną Piotra Sommera. Ze względu na duże tutaj znaczenie sztuki kompilacji podstawą do wyliczeń i omówień będą dwie Sommerowskie antologie: Artykuły pochodzenia zagranicznego z 1996 roku, gdzie znaleźli się Frank O’Hara, John Ashbery, Charles Reznikoff, Allen Ginsberg, Robert Lowell, John Berryman i E.E. Cummings, a także znacząco poszerzona jej wersja, $O$ krok od nich z 2006 roku, w której pojawili się jeszcze John Cage, Kenneth Koch i August Kleinzahler ${ }^{2}$. Spomiędzy tych

2 Teksty wszystkich tych poetów były publikowane - zazwyczaj zresztą wcześniej na łamach „Literatury na Świecie”, gdzie znalazły się dodatkowo przekłady z Williama Carlosa Williamsa i Davida Schuberta. 
transferów do rangi podmiotu dialogu podniesiony zostanie jeden twórca: John Ashbery - najbardziej emblematyczny dla podejmowanych zagadnień, szczególnie odrębny i jednocześnie wpływowy. Przedmiotem relacji między poetą a tłumaczem, dającym się opisać układem sensów będzie jeden jego wiersz, a wychylającym się poza kadr, domykającym i otwierającym odczytanie szczegółem - ostatnie w tym wierszu słowo.

\section{Tło}

Dominantą dla prezentowanych tu strategii literackich, w tym strategii przekładowej, jest odruch emancypacji, uwolnienia się i odróżnienia - silniejszy nawet od potrzeby nowatorstwa. Tak ukierunkowane poetyki nabierają wyrazu na tle nowoczesności ujmowanej w sposób manifestacyjnie alternatywny wobec utartych jej definicji. Adekwatną do takiego założenia koncepcję proponuje Marshall Berman w biorącej tytuł z Manifestu komunistycznego Marksa rozprawie ,Wszystko, co stałe, rozpływa się w powietrzu”. Amerykański filozof inaczej niż postmoderniści definiuje modernitas, która dla niego jest przede wszystkim dynamiczną epoką skoncentrowaną na życiu, budowaną przez ,wysiłki nowoczesnych kobiet i mężczyzn, którzy próbują stać się nie tylko przedmiotem, ale i podmiotem modernizacji; zapanować nad nowoczesnym światem i zadomowić się w nim" (Berman 2006: 2). Epokowy przełom polegał na zamianie odwiecznego prymatu Słowa na prymat Czynu, nieporuszonej wieczności - na wieczny ruch, lęku metafizycznego - na lęk egzystencjalny. Nowoczesne społeczeństwa pozostały - w Bermanowskiej optyce - wspólnotami o tyle, o ile wspólna jest wszystkim konieczność samodzielnego kształtowania swojego życia, wysiłku autokreacji, uniesienia jarzma wolności, jakie spadło sprawiedliwie na wszystkich. Wizja ta jest szeroka i afirmatywna - choć nazbyt otwarta, żeby być utopistyczną. Ewidentna fascynacja modernistyczną, agresywną wielkomiejskością i nadmiarem dawanej przez nią wolności dyskontowana jest bowiem podkreślaną przez autora płynnością wszystkich przyjętych założeń, także tych wartościujących. Według Bermana nowoczesność to po prostu „nowy sposób bycia, odczuwania, myślenia; to nowa formuła egzystencji pojmowanej jako całość, integralnie utkana z polityki, sztuki, literatury" - intensywne bycie w świecie, który ciągle się zmienia, dla którego przyszłość nie jest czasem dającego się zaprojektować pozytywnego rozwoju, ale nieprzewidywalnym ekstremum dynamicznej zmienności (za: Bielik-Robson 2006: IX). Nowo- 
czesność widziana przez taki pryzmat nie jest abstrakcyjna i alienująca, ale bliska jednostce, a środkiem do uświadomienia jej sobie i oswojenia mają być nie analizy filozoficzne, lecz przykłady z literatury i żywa przestrzeń metropolii, przede wszystkim Nowego Jorku - apogeum nowoczesnego rozmachu i dramatycznych konfliktów.

Wydaje się, że pomiędzy biegunami miejskości i tekstualności, życia i sztuki, funkcjonuje także „nowojorskość”, którą sam Piotr Sommer stosuje jako pewien termin i traktuje jako cechę wspólną poezji tłumaczonych przez siebie Amerykanów ${ }^{3}$. W ten sposób neutralizuje utarte i należące do amerykańskiego dyskursu pojęcie szkoły nowojorskiej, adaptowane przez niego jako określenie tego zespołu informacji, który może być przydatny w mówieniu „o nich tutaj” - nie jako zapożyczenie niejasnych na rodzimym gruncie formuł historycznych o skomplikowanym podłożu, ale poręczny klucz do oswojenia czegoś obcego (Sommer 2006: 549). Literackich „nowojorczyków” charakteryzuje flaneryzm. Energię do wierszy czerpią z zewnętrznego, wielkomiejskiego napięcia, ale też angażują się w stworzenie własnego, żywotnego, niepodległego pozatekstowej rzeczywistości języka. Ich poezję widzieć trzeba więc jako zbiór autonomicznych - na awangardową modłę - tekstów, zawierających w sobie jednak autentyczne obrazy metropolii Nowego Świata: pełnej sprzeczności, w wiecznym ruchu, pośród którego zdarzają się szczególnie newralgiczne martwe punkty (czasem momenty nudy, melancholii albo twórczej niemocy, czasem śmierci i cierpienia), szybko pochłaniane przez życie albo zagarniane przez sztukę. Obrazowana w poezji panorama Nowego Jorku jest bardzo szeroka: mieszczą się w niej robotnicy, imigranci i artyści, Brooklyn i Manhattan - realistyczne tło dla poetyckich gestów uniezwyklenia.

\section{Rama}

Za względnie adekwatną ramę krytyczną mogą tu posłużyć dwie koncepcje Marjorie Perloff, również obmyślone jako alternatywa wobec głównego nurtu. Jedna z nich, ujęta w książce Poetyki nieokreśloności, stanowiła kiedyś odcinającą się od dominującej Nowej Krytyki propozycję podziału

3 Ściślej: dziesięciu Amerykanów z antologii $O$ krok od nich, w tym w największym natężeniu tych faktycznie należących do szkoły nowojorskiej, a z nimi zapewne także malarki Jane Freilicher, autorki obrazów stanowiących komplementarną część antologii, ale również istotnej uczestniczki życia artystycznego Nowego Jorku czasów Franka O’Hary. 
modernistycznej sceny literackiej. Obok wielkich tradycji romantyzmu i symbolizmu (którym patronować mieli Baudelaire, Yeats, Eliot, Auden i Stevens) autorka dostrzegła szeroki nurt innej tradycji ${ }^{4}$, w której znalazły się dzieła między innymi Stein, Wiliamsa, Pounda, Ashbery'ego i Cage'a (zob. Perloff 1981, 2008). Fundamentem wypracowanej przez nich nieokreśloności języka miał być jego opór przed parafrazowaniem i naddanym dyskursywizowaniem. Język sam w sobie miał stanowić o kształcie i oddziaływaniu wiersza, które było szczególnie intensywne dlatego właśnie, że odsyłało do wielu znaczeń jednocześnie - wieloznaczność nie rozpraszała, ale intensyfikowała jego idiomatyczność, bo odwracając uwagę od semantyki, kierowała ją na intonację i składnię. Każda poetyka nieokreśloności miała być inna, osobna, pojedyncza, wszystkie razem jednak tworzyłyby pewną wspólnotę, odrębną wobec ustalonego kanonu.

W napisanym znacznie później Modernizmie XXI wieku, ze znamiennym podtytułem ,Nowe” poetyki, Perloff odkrywa, że awangarda z początków wieku XX odnowiła się u jego końca (i tu stawia obok siebie Gertrudę Stein i wczesnego Thomasa Eliota, a także Marcela Duchampa i Wielemira Chlebnikowa - za ich spadkobierców uznając amerykański nurt Language) (zob. Perloff 2012). Uogólniając, amerykańska krytyczka szuka ciągłości tam, gdzie inni utrwalają podział, zamiast na periodyzację stawia na kontynuację - pisze o przeoczonym, a bardzo silnym oddziaływaniu na współczesność przełomu tysiącleci tych pierwocin ruchu awangardowego, które wraz z nim samym uznano za ściśle historyczne, przebrzmiałe i zakończone porażką. Bardzo arbitralną, choć też sugestywną wyrazistość i dialektyczność sądów Perloff tonuje powszechnie wiadomy zakres jej badań, skupionych wokół ogniw pośrednich - nie radykalnych eksperymentatorów, ale poetów połowy XX wieku i ich „legendarnego «otwarcia pola»”, które z perspektywy czasu uznaje badaczka za ,swoistą, nieco rozcieńczoną kontynuację awangardowego projektu, który odnaleźć można w samym sercu wczesnego modernizmu" (Perloff 2012: 10-11). W centrum translatorskich zainteresowań Piotra Sommera od lat osiemdziesiątych znajdują się te właśnie

4 Jest to formuła zapożyczona z tytułu wiersza Johna Ashbery’ego, a jednocześnie stanowiąca modyfikację i rozwinięcie jego koncepcji ,innych Tradycji”, wyłożonej w zbiorze esejów pod tym właśnie tytułem. Różnica polega na tym, że Ashbery-poeta opowiada się za istnieniem tradycji w pełni ekscentrycznych, niedających się podporządkować żadnym uogólnieniom. Perloff jako badaczka broni natomiast, z pewną świadomą przesadą, systematyzującego dyskursu, podkreślając jedynie konieczność pluralizmu systemów (zob. Ashbery 2008: 7). 
poetyki - „otwarte i ekspansywne”, choć nieinwazyjne, bo skupione raczej na sobie niż na przebudowie świata (Sommer 1987: 110). Te pojedyncze, meandryczne nurty, czerpiące ze źródeł tak różnorodnych, że niemożliwych, ale i niekoniecznych do oznaczenia, dopiero z czasem w pewien organiczny sposób łączą się w silne prądy i są zauważane jako ożywcze i wpływowe.

\section{Technika}

Eksplorację tak widzianego dzieła przekładowego należy opatrzyć spostrzeżeniem, że w tym przypadku proces translacji poprzedza swoiście rozumiany wolny wybór poszczególnych, niezbyt licznych poetów i możliwie wielu wyjątków z ich twórczości, co należy do obranej przez Sommera strategii kompozycyjnej. Ułożone przez niego antologie pomyślane zostały nie jako reprezentacje szerokiego spektrum amerykańskiej poezji ubiegłego wieku, ale jako - słowami autora - „historia pojedynczej wrażliwości estetycznej” (Sommer 2010: 66). Specyfikę tego wyboru uwypukla Jerzy Jarniewicz w znanym podziale tłumaczy-antologistów na ambasadorów i legislatorów (Jarniewicz 2012: 23-33). Pierwsi przenoszą do rodzimej kultury kanon ustalony w kulturze oryginału, dochowując wierności jej hierarchiom i stawiając na obiektywną reprezentatywność, zadaniem drugich - do których zaliczyć trzeba Sommera - jest uzupełnienie braków w kulturze rodzimej: „przewartościowanie, za sprawą poezji przyswajanej polszczyźnie, obowiązujących w Polsce modeli poetyckich, poszerzenie ich tematyki i języka" (Jarniewicz 2012: 27-29). Sam autor Artykułów pochodzenia zagranicznego, doceniając użyteczność tej kategoryzacji, mąci jej klarowność, obstając przy tym, że u poetów obcego języka, nie wyłączając tych uznanych za wybitnych, szukał zawsze „,czegoś dla siebie”, nie przyświecały mu ambicje „legislatorskie”, sankcjonujące nowe punkty odniesień dla polskiej literatury, ale raczej ambicja zademonstrowania swojego punktu widzenia, podjęcia ryzyka własnej, niekoniecznie od razu wpływowej, „,wybiórczości”5 (Sommer 2015: 24). W takich deklaracjach trzeba zobaczyć element autokreacji,

5 Słowa „wybiórca” jako synonimu dla ,,antologisty” używa Sommer kilkakrotnie w szkicu podnoszącym kwestię sztuki układania antologii poetyckich i mieszczącym kilka ważnych sądów, między innymi i ten, że „,antologista to też autor”, a więc twórca, który wtedy tylko może stać się Jarniewiczowskim „twórcą kanonu”, kiedy wyjdzie poza schemat udostępniania poetów obcych, których ,wysoka ranga w języku oryginału od lat zazwyczaj nie ulega wątpliwości” (Sommer 1995: 10-17). 
absolutyzowania własnej suwerenności oraz niechęci do bycia uznanym za jednego z konstruktorów literackiego mainstreamu. Odbiorca skonfrontowany $\mathrm{z}$ zadekretowaną $\mathrm{w}$ ten sposób niezależnością jest niejako zobligowany pamiętać, że każdy zestaw tekstów, z którym się styka, został przefiltrowany przez wrażliwość „,wybiórcy” - że poza głosem poety cały czas słyszeć musi głos tłumacza. Przeczy to do pewnego stopnia wyznawanej przez Sommera filozofii przekładu, która daleka jest od tradycyjnie pojmowanej „wolności”, a przeciwnie - opiera się na ,antyuzurpacji”: jak najwierniejszym przełożeniu tekstu wyjściowego, przy czym wierność nie ogranicza się do nieufnie przez thumacza traktowanej dominanty semantycznej, ale rozszerza na melodię poezji nierymowanej i nienumerycznej - nieregularny rytm i znaczącą intonację wolnego wiersza (zob. Sommer 2005: 220-240). Tekst przetransferowany to tekst przeniesiony tak, aby go nie zniekształcić i nie zubożyć, a nas wzbogacić o pewność, że nie tylko otrzymujemy wiersz maksymalnie zbliżony do oryginału, ale jeszcze - ponieważ pochodzi z obcej, gruntownie jednak zbadanej przez tłumacza kultury - że powiększa się nasz zasób wiedzy.

To, co wynika z tak szkicowanej przez autora strategii, zatrzymuje się na ogólnikach niewątpliwie uczciwych, ale niepozbawionych skazy komunału. Sommer oczywiście stara się być blisko oryginału i dopracowuje swoje teksty pieczołowicie, o czym świadczą częste korekty w kolejnych przedrukach, oczyszczonych z drobnych usterek lub wzbogaconych o odnaleziony nareszcie stosowny ekwiwalent. Takie - przez większość tłumaczy uznawane przecież za obligatoryjne - założenia powinny jednak sprawiać, że sam translator chowałby się w bardzo wąskiej szczelinie pomiędzy oryginałem i przekładem, byłby jedynie narzędziem transferu, operatorem kamery. W przypadku Sommera tak się nie dzieje. Znaczna liczba tekstów towarzyszących zawsze przekładom, łączących teorię przekładu z krytyką literatury, powoduje, że świadomość obecności tłumacza jest przy lekturze wierszy trudna do uniknięcia. Stoi on obok kolejnych poetów, zdecydowanie wchodzi w kadr - łatwo sobie wyobrazić, jak negocjuje z autorami oryginałów ostateczne wersje utworów, jak pozwala im mówić, ale sam zadaje pytania, decyduje o temacie wypowiedzi, wzmacnia jedne tony, a wycisza drugie.

Nacisk kładziony przez samego antologistę na sztukę wyboru ma sprawić - i z pewnością przy niewybiórczym, całościowym czytaniu sprawia - że w polu uwagi czytelnika znajdują się nie tylko twórcy i teksty, ale kolejność ich pojawiania się, wzajemne relacje pomiędzy nimi, a także między tym, co znalazło się w książce, a całym ogromnym - i dla niewielu możliwym do poznania w oryginale - obszarem, wewnątrz którego wybór został dokonany. 
Właściwie każda dająca się dostrzec powierzchnia wspólnoty nabiera głębi dzięki świadomości wyobcowania. Wspólne dla prezentowanych poetów jest z pewnością użycie języka codzienności - ta istotna właściwość poezji amerykańskiej, której wyemancypowanie się w stosunku do poezji angielskiej zaznaczyło się nie w topice, ale w języku. Naśladuje on żywą mowę i wyzyskuje raczej jej poetycki potencjał, niż odróżnia się od niej artystyczną sztucznością. Sommer wyjątkowo stara się tę cechę w swoich przekładach zachować, często wręcz ją wyróżnia. Nie poetyzuje oryginałów, nie wprowadza szyku przestawnego ani utartych w polskiej poezji zwrotów, jednocześnie poszukując w polszczyźnie słów najtrafniejszych, to znaczy: brzmiących zgodnie z oryginałem, nawet jeśli znaczących nieco inaczej. W jego przekładach mnóstwo jest iście polskich idiomów. Odchodząc od strategii poetyzowania, popada niekiedy w manierę upotocznienia: frazeologizmy języka mówionego są tak powszechne, że czytamy polskie wiersze - przełożone z pietyzmem, ale ujawniające swoją inność wobec źródła. Widzimy pracę tłumacza, domyślamy się jego dialogu z twórcą, dla nas jednak oryginał nie przestaje być obcy, pozostaje nieobecny. Można to potraktować nie jak usterkę, ale jak demontaż iluzji bezpośredniego kontaktu, zaakcentowanie, że przekład nie powinien wcale służyć do (i tak iluzorycznego) zniesienia odległości między wierszami w różnych językach, ponieważ jego zadanie jest inne: ma on umożliwić komunikację między nimi pomimo istnienia niedającej się zlekceważyć odległości.

\section{Postaci}

Nie ulega wątpliwości, że Sommera ciekawią jego „rozmówcy”. Poszczególni poeci, nierzadko odarci ze stereotypu, a więc ukazując się na nowo, faktycznie mówią - do tłumacza i poprzez niego do odbiorcy przekładu - wyrazistymi głosami. Zaznaczony w tytule niniejszego szkicu zakres pomiędzy poezją bitnikowską a wierszem projekcyjnym odzwierciedla oś rozwojową pewnego amerykańskiego idiomu. Linia ta rozciąga się między dwoma rodzajami emancypacji i przebiega od wyzwolenia ,psychologicznego" Allena Ginsberga do wyzwolenia „technicznego” Charlesa Olsona (Ashbery 1986: 38). Ten pierwszy w istocie pojawia się u Sommera, choć tylko śladowo reprezentuje Beat Generation z jej kontrkulturową swobodą i ostentacyjnym nonkonformizmem, drugi - nieprzekładany przez niego przedstawiciel Black Mountain z San Francisco - stanowi tutaj swoisty 
negatyw filozofii i praktyki poetyckiej Franka O'Hary, ikony szkoły nowojorskiej ${ }^{6}$. Jeśliby zaś postarać się o przydającą wyrazistości opozycyjność, to należałoby może ustawić perspektywę pomiędzy ,globalistą Ginsbergiem” i „detalistą O’Harą" (Sommer 2005: 102). To, co ważne jako przedmiot transferu, istotne $\mathrm{w}$ swoim czasie nowatorstwo, to uwolnienie poezji od konwencjonalnych reguł obrazowania i ujęzykowienia oraz zaznaczenie ich odrębności - od siebie i rzeczywistości pozatekstowej: tego, że język jest w wierszu autonomiczny, a rola obrazu nie ogranicza się do tradycyjnie pojmowanej mimetyczności. Pomieszczone w antologii wybory nie epatują eksperymentem, ale rzeczywiście pokazują szereg odrębnych, wyemancypowanych języków poetyckich.

Allen Ginsberg pojawia się nie jako autor skandalizującego Skowytu, ale jako poeta ściszonych osobistych zwierzeń, staroświecki w dawno ustatecznionym młodzieńczym buncie i kontestujący własną legendę, przesłaniającą to, co nowy wybór próbuje odsłonić: psychologiczną wnikliwość, głęboki ton elegijny, skłonność do autoironii i otwarcie na dialog. Zaskakująco podobnie brzmi obiektywistyczna poezja Charlesa Reznikoffa - bacznego obserwatora życia wielkiego miasta, a zwłaszcza jego społecznych marginesów, nie tych wysuniętych w ekscentryzm patologii, ale cichych, ukradkowych, niezauważalnych dla świata. Jego dykcja oscyluje pomiędzy neutralnym językiem lapidarnych opisów a starotestamentową frazą wierszy kojarzących przelotne obserwacje z biblijnymi księgami, czasem łącząc je w takiej miniaturze jak ,kominy fabryk - nasze cedry Libanu”, czasem wypełniając odległość wyznaniami amerykańskiego Żyda, który, choć nie widział zza Oceanu Zagłady, napisał po niej Kadysz. Kronikarzem miasta jest także zamykający $O$ krok od nich August Kleinzahler. Jego szkice z przestrzeni ,pełnej migawek i epizodów” są bardziej fragmentaryczne i migotliwe; poetyckie nastroje buduje się na ostrzejszych dysonansach (między tonem wysokim i niskim, barwą pastelową i jaskrawą), przez co nabierają one chłodnej ekspresyjności. Wyznania konstruowane są tu z dystansu wobec siebie i otoczenia, ale i z wnętrza miasta - „Ogromnej oddychającej komórki”, która „nocą żeruje”.

${ }^{6}$ Szczególnie jeśli przyjąć za Marjorie Perloff, że słynny O’Harowski manifest personizmu jest ,prawdopodobnie cienką parodią manifestów z kręgu Black Mountain, a zwłaszcza Projective Verse Olsona, owego Świętego Tekstu roku 1950” (Perloff 1986: 69).

7 Wszystkie cytaty z wierszy, jeśli nie zaznaczono inaczej, pochodzą z antologii $O$ krok od nich (za: Sommer 2006). 
Inną grupę stanowią poeci nastawieni na bardziej otwarte autoanalizy. Robert Lowell, który z tradycjonalisty zmienił się w nowatora za sprawą prekursorskiego tomu Life Studies, dopiero w wierszach powstałych po tym przełomie jest przez Sommera przekładany i jawi się w tych tłumaczeniach jako mistrz formy i zarazem sprawozdawca $\mathrm{z}$ własnych egzystencjalnych lęków: „biedny, zmierzony, neurotyczny człowiek”, innymi słowy: „Uwikłany w konflikty, przekraczający zastaną rzeczywistość, zarazem bardzo intymny i bardzo publiczny - w życiu i w poezji”. Obsesja życia i śmierci, ale też obsesja pisania wiąże z nim Johna Berrymana, w którego wierszach więcej jest jednak pesymistycznej ironii i humorystycznego deliryzmu. Poeta wymyśla postać uznawaną za jego alter ego, którym jest w Piosenkach snu (anty)bohater liryczny - „ten zgorzknialec Henry, pełen umarłej miłości, / Makbetycznego niepokoju, odambitniony, opłakujący / to całe niewyobrażalne a konieczne coś". Za mętnymi, rozedrganymi potokami obrazów podąża składnia - nienormatywna, o nienaturalnym szyku zdań, przemyślnie bełkotliwa. Poeta rejestruje dławiący nadmiar, ujmuje zgiełk rzeczy w karby oryginalnej, bardzo zwartej formy językowej. Równie swoista jest formalna strona twórczości E.E. Cummingsa, nawet jeśli czasem sprowadza się ona do „dziwacznej typografii” (Sommer 2005: 213). To znów poeta erotyczno-tanatycznych i estetycznych obsesji, pacyfista, ironista, konceptualista - jedyny Sommerowski Amerykanin piszący wiersze do druku, a nie do czytania na głos, niekiedy w istocie nieprzetłumaczalny, mimo wszystko jednak pozostający wyrazistą osobowością poetycką, rozpoznawalną od pierwszego spojrzenia na:

najmniejszy

wiersz

(z malutkimi uszami i widzisz?

rusza ogonem)

(uciekła)

„mysz”

Podobnie jak na takie utwory, patrzy się na stereotypowo wręcz awangardowe wiersze Johna Cage'a, których jednak w Sommerowskiej antologii zabrakło. Znalazły się w niej natomiast jego anegdotyczne poematy prozą, narracyjne, operujące prostotą przejrzystego języka i ukształtowania syntaktycznego. Jeśli są w nich humor i ironia, to lekko utrzymujące się na powierzchni fabuł, przenoszące się na fragmenty zupełnie neutralne 
- i w rezultacie wszechobecne. Tak jak prozy Cage’a, także „wiersze sceniczne" Kennetha Kocha służą w antologii temu, by poszerzyć zakres poetyk. Równie humorystyczne, znacznie częściej jednak bywają parodystyczne. Niektóre z Tysiaca sztuk awangardowych są w istocie - jeśli to słowo wystarczająco ironiczne - paraawangardowe, kpią bowiem z wszelkiego klasycyzmu, ale i wszelkich minionych (i chybionych) prób nowatorstwa.

Koch wprowadza w krąg szkoły nowojorskiej, a tym samym prowadzi do Franka O’Hary. Wątek tej twórczości należy zacząć od sygnalizowanego punktu odniesienia, którym będzie wiersz projekcyjny - istota teorii Charlesa Olsona, twierdzącego, że poezja ,,aby przetrwać, musi się oprzeć na oddechu, na funkcji oddychania człowieka, który pisze, i tych, którzy go słuchają", ma kierować się do ucha, a nie do oka czytelnika, być organiczną całością, nie dzieloną w sztuczny sposób na linijki i strofy (za: Truszkowska 1976: $282)^{8}$. Podstawą wiersza powinna być jego kinetyka - uwalniane podczas czytania ładunki energii. Koresponduje z tym O'harystyczna poezja radosna, spontaniczna, pisana pośpiesznie potocznym językiem, rejestrująca przelotne powszednie sytuacje. Dla Sommera O'Hara jest poetą wyjątkowym - jako najważniejszy być może z tych, którzy w swoim czasie grali o wysoką stawkę: nowy kształt wiersza, ,w którym będzie można rozpoznać siebie i Amerykę", i nowy język poetycki, który - po lekcjach Whitmana i Williamsa - „miał być przystępny, «niski», a ekspozycja «ja» wyrazista” (Sommer 1987: 228). Liryka O’Hary jest całkowicie osobista i skrajnie wizualna, unaocznia i aktualizuje bieżące - kiedyś - życie Nowego Jorku. Personistyczne umieszczenie wiersza pomiędzy poetą a odbiorcą sprzyja entuzjazmowi ożywczo zmieszanemu z ironią: ,Ach! / czytelniku! odwracasz stronę / moje wiersze patrzą na ciebie ty / na nie, może nie?’. Rozległa fraza mieści zaś zarówno detal historyczny, jak i szeroki kontekst kulturowy, a wreszcie - całą ,nowojorskość”, widoczną dobrze we wszystkich niemożliwych do streszczenia Wierszach bez konkretnego tytułu.

Stąd tylko krok do Johna Ashbery’ego - tego przedstawiciela szkoły nowojorskiej, który zyskał największą sławę i uznawany dziś bywa za najwybitniejszego współczesnego poetę języka angielskiego, choć długo pozostawał na obrzeżach głównej sceny literackiej, a niezmiennie rozpoznawany

${ }^{8}$ Należałoby może mówić o „,wersie projekcyjnym”, co jest pojęciem stosowanym w nietłumaczonym na język polski eseju Olsona. „Wiersz projekcyjny” jest jednak sformułowaniem zyskownie dwuznacznym - jako określenie dla utworu i linijki w tekście - jeśli pamięta się, że mowa o poetykach, w których granica między poezją i prozą nie zasadza się na wersyfikacji (por. Olson 1950). 
jest jako twórca hermetyczny. Sam zaś konstatował ironicznie, że niegdyś nie mieścił się w granicach nowoczesności, ale w końcu granice przesunęły się na tyle, by „objąć jego osobliwość” (zob. Ashbery 2013: 131). Jego zanurzona $\mathrm{w}$ cywilizacyjnym chaosie poezja rejestruje - i emituje - różne komunikaty naraz, co da się ująć wyrwanym z kontekstu hasłem: „Od dawnaśmy nie słyszeli tylu wieści, takiego szumu”. Charakterystyczny dla niego wielki rozmach i opór przed płynnym, a więc łatwym łączeniem słów inny tłumacz ujmuje obrazowo tak: ,jak śruba rozłupane kości nadgarstka, tak zdanie Ashbery' ego ściąga i zwiera najbardziej od siebie oddalone obszary mowy pisma" (Sosnowski 2010: 43). I jest to w istocie poezja wielkich różnic i kontrastów. Obok niezwykle długich poematów medytacyjnych trafiają się miniatury złożone tylko z tytułu i puenty. Rozległość pól tekstowych, wśród których szukać trzeba punktów orientacyjnych, sąsiaduje z eliptycznością, swoistą „opustkowością" krótkich form. Egzystencjalny ton miesza się $\mathrm{z}$ autotelizmem, pojedynczość głosu $-\mathrm{z}$ polifonią.

Dające się między poetami odnaleźć powiązania potwierdzają wspólnotę miejsca i strategii wyodrębnienia: piszą oni o różnych rzeczach, ale wszyscy w tym samym wielkim mieście - różnymi językami, ale wszystkim zależy na odnalezieniu własnego. To, co antologista nazywa niejednokrotnie „ciekawym” albo „żywym” - używając subiektywnych określeń niedających się zweryfikować, a pozostawiających jedynie pewną domyślną wiedzę o tym, kiedy wiersz jest nieciekawy albo martwy - wpisuje się dobrze w ,cudzysłowowe”, niedookreślone sformułowania Perloff i Ashbery’ego. Są to „nowe” poetyki, należące do ,innych” tradycji - ich innowacyjność zawsze można podważyć, ale też nie sposób w pełni jej zanegować, ponieważ cały czas, także w przekładach, rozwijają się one i zaprzeczają nie tylko ustalonym tradycjom, ale też samym sobie.

9 Jako „opustki” tłumaczy Andrzej Sosnowski living out - trudne do przełożenia sformułowanie, które brytyjski badacz uznaje za określenie ,ekskluzywnego, sztucznego języka zaznaczającego granicę wokół poezji” (zob. Earnshaw 2007: 216), a które odnosi się do charakterystycznych dla Ashbery'ego radykalnych, pustych elips bez domyślnego wnętrza. Jest to - w skali mikro, ograniczonej do jednego słowa - przykład zdecydowanie odmiennego od taktyki Sommera wolnego przekładu. 


\section{Dialog}

U Ashbery'ego, przy całej woli odróżnienia i nieustannego postępu, warto być może poszukać śladów stałości, obok precedensów - zasad i twórczych powtórzeń. Chodzić będzie o wiersz-program, wiersz-symbol, „wierszo-obraz"10. Uchwytny jego schemat jest taki: personistyczne otwarcie, z nutą afirmacji, na wysokim tonie - następnie ruchliwe, chaotyczne centrum, kolaż rzeczy i słów z różnych rejestrów - a wreszcie: podejrzanie deklaratywne, orzekające zakończenie. Cały wiersz zbudowany jest ze zdań: zwykle krótkich, na miarę rwanego oddechu, a czasem dłuższych i wtedy przełamanych przerzutnią na słowie w jakiś sposób szczególnym. Już w tytule dowodzi się tu, że poezja ma być jak obraz, ale od początku do końca lektury nie da się odwrócić uwagi od języka.

A imięjej , Ut pictura poesis” otwiera słynny niebieski numer „Literatury na Świecie” z 1986 roku, od którego rozpoczęły się rozmaicie widziane i oceniane dzieje „o'haryzmu” i ,ashberyzmu” (por. np. Maliszewski 2008: 111-114; Burkot 2015: 245-246). Przekład wiersza - zgodnie ze zwyczajem tłumacza w kilku miejscach zmieniony w porównaniu z pierwszą wersją znajduje też miejsce w antologii. Zaczyna się od gry z czytelnikiem - dość jeszcze przejrzystej. Inicjalne dla utworu zdania są pisane jasnym językiem, tłumaczone dosłownie, poetyzowane jedynie przerzutniami:

Nie możesz już tego tak powiedzieć.

Jeśli nie daje ci spokoju piękno, musisz

Wyjść na dwór, na polanę,

I odetchnąć.

Taki wstęp, sprawiający wrażenie dalszego ciągu jakiejś ożywionej rozmowy, kierowany jest wprost do nieokreślonego „drugiego”. Brzmi w nim nakaz - paradoksalny - wyswobodzenia się. Natrętne przywoływanie „ty” lirycznego nie pozwala o nim zapomnieć ani dobrze go określić. Kolejne zdania odwlekają wstawioną w środek wiersza puentę:

${ }^{10}$ Złożenie to pochodzi z omawianego tu wiersza $A$ imię jej... i jest o tyle interesujące, że pojawia się dopiero w ostatniej wersji przekładu, który przez lata funkcjonował z formułą: „obrazko-wiersz”, użytą i na łamach „Literatury na Świecie”, i w Artykułach pochodzenia zagranicznego. Trudno orzec, dlaczego poem-painting widział Piotr Sommer tak długo jako „obrazko-wiersz”, zmieniając kolejność cząstek składowych, obniżając neutralny ton i rezygnując z pewnego fonetycznego efektu uskoku, który w oryginale daje wybuchowe ,p” po „m”, a w nowym tłumaczeniu - podwojenie „o”. 
Cokolwiek ci się zdarzy zabawnego

Na pewno będzie w porządku. Byłoby dziwne, gdybyś

Wymagał więcej, ty, co tak wielu masz kochanków,

Ludzi, którzy cię cenią i gotowi będą

Coś dla ciebie zrobić, chociaż ty sądzisz

Że to niesłuszne, że gdyby znali cię naprawdę...

I tyle autoanalizy.

„Zwrot do drugiego” okazuje się wreszcie „zwrotem do siebie” - autoanalizą, choć przecież i czymś więcej niż nią. Po rozproszeniu, dekoncentracji podmiotu wobec natłoku zewnętrznego szumu następuje szereg uwag o tym, z czego wiersz mógłby, na przykład, powstać:

A teraz

O tym, co włączyć do twego wierszo-obrazu:

Kwiaty są zawsze miłe, zwłaszcza ostróżka.

Imiona chłopców, których kiedyś znałeś i ich saneczki,

Rakiety kosmiczne są niezłe - czy aby jeszcze istnieją?

Jest masa innych rzeczy tego samego gatunku

Co wymienione wyżej.

Jest więc mnóstwo możliwości, idąc zaś za wyraźnie już obniżonym tonem wiersza w przekładzie - masa możliwości, i to niezłych, a dla nich - jasne prawidła, praktyczne egzempla:

Trzeba następnie

Znaleźć parę słów ważnych i całe mnóstwo w niższej tonacji,

Co brzmią nieciekawie.

Czasowniki występują tu w różnych osobach, a najważniejszy: „napisać” - bezosobowo. Zaimki także są różne, a więc podmiotowość jest niepewna, płynna, co potęgują nagłe zwroty akcji (w każdym zdaniu wykonuje się inną czynność) i tonacji (zdecydowanie nisko, a przy tym dynamicznie brzmiąca „huśtawka” poprzedzona zostaje wysokim rejestrem retardacyjnych „monotonnych testamentów”) oraz efektowne, dziwaczne obrazy:

\section{Podeszła spytać}

Czy kupię od niej biurko. Nagle ulica popadła

W obłęd i zgiełk japońskich instrumentów.

Wokół rozrzucano monotonne testamenty. Jego głowa

Sczepiła się z moją. Byliśmy huśtawką. 
Ostatnie wypowiedzenie rozpoczyna, nie całkiem normatywnie, spójnik:

\section{I trzeba by}

Napisać nieco o tym, jak wpływa

$\mathrm{Na}$ ciebie kiedy piszesz wiersze

Ta niezwykła surowość prawie pustego umysłu

Co zderza się z soczystym, jak u Rousseau, listowiem swego

pragnienia, żeby zakomunikować

Coś między oddechami, choćby tylko przez wzgląd

$\mathrm{Na}$ innych i ich pragnienie, by cię zrozumieć i opuścić

Dla innych środków komunikacji, ażeby zrozumienie

Się zaczęło, a zaczynając zostało uchylone.

Oto bardzo długie i płynne zdanie, które trzeba przerwać na zaczerpnięcie powietrza, właśnie gdy trzeba „zakomunikować / Coś między oddechami”. Wiersz popada wreszcie w przesadę, ale nie kończy się ani nie wyczerpuje - przeciwnie, wygrywa walkę o prawo do niejasności, znosi imperatyw jakiejkolwiek pewnej interpretacji - w poezji, która mówi o sobie, jest autoteliczna i domyka się, by na końcu znowu się otworzyć. Taki utwór przetransferowany do polszczyzny jest pojedynczym tekstem, otwartym na różne odczytania (i wszystkie uchylającym), lecz koncentruje w sobie jeszcze inne elementy - zasadę poetyki Ashbery’ego, a także, dzisiaj, całą jego sławę i trudny do określenia, ale z pewnością zaistniały w polskiej poezji wpływ, datowany od pierwszej publikacji tego wiersza. Skupia jak w soczewce wiele współczynników wielkiego lirycznego ożywienia lat dziewięćdziesiątych: potrzebę nowości, inności i nieokreśloności przy zachowaniu wyrazistej podmiotowości i komunikacji z czytelnikiem.

\section{Ostatnie słowo}

Ostatnie słowo utworu, w oryginale undone, oddane zostało poprzez imiesłów ,uchylone”, dający się użyć jako wyjątkowo poręczna, zyskana w przekładzie metafora ${ }^{11}$. Po angielsku wygłos wiersza znaczy jakby prościej:

${ }^{11}$ Andrzej Sosnowski wprawdzie metafory nie dostrzega, uściśla jedynie: „On to napisał odrobinę mocniej: undone. Czyli jak gdyby: zniweczone” (Sosnowski 2013: 71). Z figurą uchylenia dobrze natomiast koresponduje forsowane przez Pawła Marcinkiewicza w książce o Ashberym pojęcie opening/closing gesture - ,gestu otwarcia/zamknięcia wiersza” (Marcinkiewicz 2014: 8). 
to zwykła negacja, niedokończenie, zatrzymanie w działaniu, dokonująca się ciągle i niedokonana czynność: in doing so be undone. Uchylić rozumienie to ciągle je uniemożliwiać i dekonstruować, a tym samym stwarzać: „tak właśnie pojawia się zrozumienie, to jakby tkanina Penelopy, która się nieustannie pruje, kiedy już jest niemal gotowa - podobnie my nabieramy wiedzy i doświadczenia" (Ashbery 1986: 193-194). Na podobne obrazy intuicja naprowadziła Andrzeja Sosnowskiego, który stwierdza:

W tym miejscu już byliśmy: ,ażeby zrozumienie / Się zaczęło” to jest nasze „tkanie” (...); zrozumienie ,uchylone”, zniweczone - to prucie. Naprawdę nie chcę wymówić tego słowa, ale cóż, niestety, ironia (Sosnowski 2013: 72).

Mowa o ironii ujmowanej ironicznie, niweczącej się poprzez otwarcie na impuls entuzjazmu. Jeśli coś pozwala połączyć sprzeczności, to założenie, że są wymienne - i tak w tym utworze wymieniają się sprzeczne języki i przeciwstawne strategie - uruchamiane, więc urzeczywistniane w czytaniu. Wiersz niezrozumiały, antyhermetyczny może więc być zarazem komunikatywny, wiersz nowatorski może być kontynuacją całej długiej tradycji (zwłaszcza jeśli jest to tradycja artystycznego zniekształcania rzeczywistości - nie przedstawieniowa, ale przetwarzająca).

We fragmentarycznym i ,nieoficjalnym”, bo służebnym wobec tekstu krytycznego przekładzie Bohdana Zadury kończy się ten utwór „mniej więcej" tak:

Coś między oddechami, żeby tylko ze względu na innych i ich chęć zrozumienia ciebie i porzucenia

Dla innych centrów przekazu rozumienie

Mogło się rozpocząć i rozpoczęte nie skończyć się nigdy (Zadura 2007: 297-298).

Ekwiwalent leksykalny jest może nawet trafniejszy, znaczenie zostaje zachowane, ale ciężkie, ostateczne ,nigdy” zamyka wiersz - i tym samym go redukuje. U Sommera całość zyskuje na wieloznaczności i nieoznaczoności. W wysokim rejestrze słowo ,uchylone” wskazuje na unieważnienie czegoś, w niższym - na częściowe otwarcie i prostą fizyczną czynność. Uchyla się okno z widokiem na Nowy Jork, które - jako temat obrazów Jane Freilicher - jest klamrą spinającą ostatnią Sommerowską antologię. Puentą książki są zaś dopiski do Amerykanów, w tytule których: Z tej i z tamtej strony szyby, autor określa trafnie swoją sytuację jako tłumacza - pozostającego ciągle 
pomiędzy dwiema przestrzeniami, z których jednej jest przypisany, drugą natomiast musi zdobywać transgresyjnym ruchem, aby z niej przetransferować coś „do siebie” (Sommer 2005). Ostatecznie pozostaje bowiem „z tej strony” - z wewnątrz i na dystans, odrębnie, ale absorbując światło z zewnątrz i emitując własne, tak żeby pogranicze między oryginałem i tłumaczeniem było szerokie i otwarte na możliwości. Uchylenie na obce języki umożliwia „napływ nowego oddechu na kartkach”. Uchylić znaczy dopuścić inne powietrze, otworzyć się, ale i zostać u siebie. Widok na obcą metropolię jest szeroki, pełen detali, powinien być oglądany uważnie i zapisywany z wyczuciem, choć i tak:

Aby uniknąć ewentualnej nudy i piętna

Zbyt wielkiej intuicji cały ten widok

Osłania szyba.

Obraz szyby kieruje znów nieomylnie do metafory ekranu, uprawomocnia ujęcie w planie amerykańskim i uzmysławia - obok szeroko omówionego zysku z transferu - związaną z nim zbawienną utratę. Transfer o tyle jest przeniesieniem, o ile zbliżony jest do projekcji filmu: pokazuje tutaj coś, co zaistniało tam i niesie z sobą całą nieobecność nieujętej w kadrze tamtejszej rzeczywistości - wielki obszar, którego nie można doświadczyć inaczej niż poprzez fragment. Tekst przekładu jest nośnikiem obrazów, rejestrowanych i uruchamianych za pomocą języka poetyckiego, który jest już językiem tłumacza, od-twarzającego wiersze zapisane przez poetów wybranych przez niego jako potrzebni - z dystansu - środowisku, którego sam jest częścią. $\mathrm{Na}$ zbudowanym przez niego kanonie twórców i tekstów - „,nowym” i ,innym” - powstaje pełna dialektycznych sprzeczności metropolia interpretacji, ocen i kontynuacji, dla których nie(do)określoność znaczenia i wartości stanowi kłopot, ale i ożywczy impuls. Nie absolutyzuje się go jako jedynego czy nawet najważniejszego dla przemian rodzimych, zróżnicowanych, zakorzenionych w tutejszej rzeczywistości poetyk, jest jednak istotny i rozpoznawalny - także ze względu na forsowany przez thumacza-antologistę dogmat o autorstwie i wolności przekładów oraz wyborów wierszy. 


\section{Bibliografia}

Ashbery J. 2008. inne Tradycje, przeł. J. Fiedorczuk, J. Jarniewicz, T. Pióro, P. Sommer, A. Sosnowski, Kraków: Korporacja Ha!art.

- 2013. Jeśli ci się spodoba, to znaczy, że zrozumiałeś, w: G. Jankowicz, Cmono. Rozmowy z pisarzami, Poznań-Kraków: Wydawnictwo Poznańskie.

1986. Przedmowa do tomu „, The Collected Poems of Frank O'Hara”, przeł. A. Szuba, „Literatura na Świecie” 7.

Berman M. 2006. „,Wszystko, co stałe, rozpływa się w powietrzu”. Rzecz o doświadczeniu nowoczesności, przeł. M. Szuster, Kraków: Universitas.

Bielik-Robson A. 2006. Życie i cała reszta: Marshalla Bermana marksizm romantyczny, w: M. Berman, ,Wszystko, co stałe, rozptywa się w powietrzu’. Rzecz o doświadczeniu nowoczesności, przeł. M. Szuster, Kraków: Universitas.

Brzostowska-Tereszkiewicz T. 2004. Komparatystyka literacka wobec translatologii. Przegląd stanowisk badawczych, „Przestrzenie Teorii” 3/4.

Bukowski P., Heydel M. (red.). 2009. Współczesne teorie przekładu. Antologia, Kraków: Znak.

Burkot S. 2015. W poszukiwaniu tożsamości. Szkice o współczesnej literaturze, o dziełach $i$ autorach, Kraków: Wydawnictwo Naukowe Uniwersytetu Pedagogicznego.

Earnshaw S. 2007. The Handbook of Creative Writing, Edinburgh: Edinburgh University Press.

Jarniewicz J. 2012. Gościnność słowa. Szkice o przekładzie literackim, Kraków: Znak. Maliszewski K. 2008. Po debiucie. Dziennik krytyka, Wrocław: Biuro Literackie.

Marcinkiewicz P. 2014. Oni przybyli, żeby wysadzić Amerykę. John Ashbery i dwudziestowieczne awangardy amerykańskie, Mikołów: Instytut Mikołowski.

Olson Ch. 1950. Projective Verse, http://www.poetryfoundation.org/learning/ essay/237880 [dostęp: 11.10.17].

Perloff M. 2012. Modernizm XXI wieku. „,Nowe” poetyki, przeł. K. Bartczak, T. Cieślak-Sokołowski, Kraków: Universitas.

1986. ,, Surowe” $i$,,gotowane”, przeł. J. Kutnik, „Literatura na Świecie” 7. 2008. Skąd wzięła się ,, araukaria z Norfolk Island”?, rozmowa G. Jankowicza, „Odra” 10.

1981. The Poetics of Indeterminacy: Rimbaud to Cage (Avant-Garde \& Modernism Studies), Princetown: Northwestern University Press.

Płażewski J. 1961. Język filmu, Warszawa: Wydawnictwa Artystyczne i Filmowe.

Słownik języka polskiego PWN, http://sjp.pwn.pl/szukaj/transfer.html [dostęp: 11.10.17]. Sommer P. 2015. Co robi zdanie?, w: Z. Zaleska, Przejęzyczenie. Rozmowy o przekładzie, Wołowiec: Czarne.

- 2006. O krok od nich. Przekłady z poetów amerykańskich, Wrocław: Biuro Literackie.

1987. „O krok od nich” (Szkic do portretu wierszy Franka O'Hary), w: F. O'Hara, Twoja pojedynczość, przeł. P. Sommer, Warszawa: Państwowy Instytut Wydawniczy. 2005. Po stykach, Gdańsk: słowo/obraz terytoria. 
1995. Smak detalu i inne ogólniki, Lublin: Stowarzyszenie Literackie „Kresy”. 2010. Ucieczka w bok (pytania i odpowiedzi), Wrocław: Biuro Literackie.

Sommer P. (red.). 2016. O nich tutaj (książka o języku i przekładzie), Kraków: Instytut Książki - Literatura na Świecie.

Sosnowski A. 2013. Stare śpiewki (sześć godzin lekcyjnych o poezji), Wrocław: Biuro Literackie.

2010. Trop w trop. Rozmowy z Andrzejem Sosnowskim, Wrocław: Biuro Literackie.

Truszkowska T. (red.). 1976. Wizjonerzy i buntownicy. Wiersze współczesnych poetów amerykańskich, Kraków: Wydawnictwo Literackie.

Zadura B. 2007. Szkice, recenzje, felietony, t. 2, Wrocław: Biuro Literackie. 